\title{
HBsAg, Anti-HBs and Anti-HCV Seropositivity Rates among Pregnant Women Attending a University Hospital in Zonguldak
}

\author{
Zonguldak llinde Üniversite Hastanesine Bașvuran Gebelerde HBsAg, Anti-HBs ve Anti-HCV \\ Seropozitiflik Oranları
}

\author{
Aynur AYNIOĞLU1, Öner AYNIOĞLU2, Tarık AKAR3, Mehtap AYDIN4, Elif Sargın ALTUNOK5
}

\author{
1Zonguldak Atatürk State Hospital, Clinic of Clinical Microbiology and Infectious Diseases, Zonguldak, Turkey \\ 2Bülent Ecevit University Faculty of Medicine, Department of Gynecology and Obstetrics, Zonguldak, Turkey \\ ${ }^{3}$ Bülent Ecevit University Faculty of Medicine, Department of Gastroenterology, Zonguldak, Turkey \\ ${ }^{4}$ Başkent University Health Clinical Research and Application Centre, Clinic of Clinical Microbiology and Infectious Diseases, Istanbul, Turkey \\ ${ }^{5}$ Bitlis State Hospital, Clinic of Clinical Microbiology and Infectious Diseases, Bitlis, Turkey
}

\begin{abstract}
Objective: To explore the HBV and HCV seroprevalence rates among pregnant women attending the Obstetric Outpatient Unit at the Medical Faculty of Zonguldak Bülent Ecevit University and to provide contributory data to the already existing data from the other geographical regions of Turkey.

Materials and Methods: HBsAg, anti-HBs and anti-HCV seropositivity rates were retrospectively investigated among a total of 1084 pregnant women attending the Obstetric Outpatient Unit at the Medical Faculty of Zonguldak Bülent Ecevit University between January 2012 and January 2014 Serum assays were performed using a chemiluminescence immunoassay method according the manufacturer's instructions (Cobas e 411 Analyzer, Roche Diagnostics, Mannheim, Germany). Statistical analyses of the study data were performed using SPSS 18.0 software package (SPSS Inc., Chicago IL, USA).

Results: The mean age of the 1084 pregnant participants was $29.12 \pm 5.48$ years (min: 17 , max: $46 \mathrm{y}$ ) and the average gestational age was $10.7 \pm 4.64$ weeks. HBsAg, anti-HBs, and anti-HCV detection rates were $4 \%(n=43), 7.3 \%(n=79)$, and $0.6 \%(n=7)$, respectively. With regard to age groups, HBsAg was positive in $3.1 \%, 3.7 \%$, $4.4 \%$, and $5.9 \%$ of the women who were below 20 years of age, between 21 and 30 years of age, between 31 and 40 years of age, and over 40 years of age, respectively.

Conclusion: While similar rates of seroprevalence for HBsAg and anti-HCV were found as compared to the previous reports from Turkey, anti-HBs positivity rates were lower than that in most of the previous reports.
\end{abstract}

Key Words: HBV, HCV, seroprevalance, pregnancy, antenatal

Conflict of interest: The authors reported no conflict of interest related to this article.

\section{ÖZET}

Amaç: Bu çalışmada, Zonguldak Bülent Ecevit Üniversitesi Tıp Fakültesi Hastanesi, Kadın Hastalıkları ve Doğum kliniğine başvuran gebelerde HBV ve HCV seroprevalans oranlarının araştııılması ve elde edilen oranların ülkemizin farklı yerlerindeki oranlarla karşılaştıılarak ülkemiz verilerine katkı sağlanması amaçlanmıştır.

Gereç ve Yöntemler: Bülent Ecevit Üniversitesi Tıp Fakültesi Kadın Hastalıkları Doğum kliniğine Ocak 2012-Ocak 2014 tarihleri arasında başvuran 1800 gebenin $\mathrm{HBsAg}$, anti-HBs ve anti-HCV seropozitiflik oranları retrosektif olarak incelenmiştir. Verileri yeterli olan 1084 gebe çalışmaya dahil edilmiştir. Hastaların serumları kemilümünesans immünassay yöntemi ile üretici firmanın (Cobas e 411 Analyzer, Roche Diagnostics, Mannheim, Germany) önerilerine göre çalışılmıştır. Elde edilen veriler SPSS 18.0 (SPSS Inc., Chicago IL, USA) paket programı kullanılarak istatiksel değerlendirilmesi yapılmıştır.

Bulgular: Çalışmaya alınan 1084 gebenin yaş ortalaması $29,12 \pm 5,48$ (min: 17, max: 46), ortalama gebelik haftası 10,7 $\pm 4,64$ idi. HBsAg pozitifliği \%4 ( $n=43)$, anti-HBs \%7,3 ( $n=79)$, anti-HCV \%0,6 ( $n=7)$ oranında bulunmuştur. HBsAg pozitifliği 20 yaş altında \%3,1, 21-30 yaş arası $\% 3,7,31-40$ yaş arası $\% 4,4,40$ yaş üstü ise $\% 5,9$ olarak saptand.

Sonuç: Sonuç olarak çalışmamızda HBsAg ve anti-HCV seroprevalansı ülkemizde yapılan diğer çalışmalarla benzer oranda bulunurken, antiHBs pozitifliği ise bazı çalışmalar ile benzer sonuçlarda olsada, birçok çalışmaya göre düşük oranda saptanmıştır.

Anahtar Kelimeler: HBV, HCV, seroprevalans, gebelik, doğum öncesi takip

Çıkar çatışması: Yazarlar bu makale ile ilgili olarak herhangi bir çıkar çatışması bildirmemişlerdir. 


\section{Introduction}

Hepatitis B virus (HBV) and hepatitis C virus (HCV) infections represent major public health problems both in Turkey and globally (1). More than 2 billion people have been infected with HBV and approximately 350-400 million of them have chronic HBV infection. Turkey has intermediate endemicity of HBV infection with the prevalence varying between 2 and $7 \%(2,3)$. HBV infection may occur via parenteral or percutaneous routes; horizontal transmission through mucosal contact with infected blood or bodily secretions and vertical transmission during the perinatal period (4). Perinatal transmission accounts for $40-50 \%$ of HBsAg carriers. On the other hand, $\mathrm{HBeAg}$ positivity increases the transmission rate from mothers to newborns, with approximately $90 \%$ of infants who acquire HBV infection from their mothers at birth become chronically infected (5).

Nearly 170 million individuals worldwide are infected with $\mathrm{HCV}$, and 1 to $3 \%$ of the Turkish population has been found to be infected with HCV (6). Although parenteral route is the principal form of the transmission, vertical transmission has also been reported (7). Transmission risk of $\mathrm{HCV}$ from infected pregnant women to their infant is $2-8 \%$ (8). Therefore, screening pregnant women for $\mathrm{HBV}$ and $\mathrm{HCV}$ is of great importance in preventing mother-to-child transmission. The seropositivity rates for $\mathrm{HBsAg}$ and anti-HCV in a group of women attending to the Obstetric Outpatient Unit was similar to that previously reported in Turkey. However, despite similarities with some previous figures, anti-HBs positivity rates were lower than that reported by the majority of other studies. In this study, our objective was to examine the $\mathrm{HBV}$ and HCV seroprevalence in pregnant women attending our unit and to compare our findings with that of previous reports to contribute to the existing national data.

\section{Materials and Methods}

HBsAg, anti-HBs and anti-HCV seropositivity rates were retrospectively examined among a total of 1800 pregnant women who attended the obstetrics outpatient clinics at the Medical Faculty of Zonguldak Bülent Ecevit University between January 2012 and January 2014.

The data of 1084 pregnant women were deemed adequate for inclusion. Serumassays were performedusing achemiluminescence immunoassay method according the manufacturer's instructions (Cobas e 411 Analyzer, Roche Diagnostics, Mannheim, Germany). Statistical analyses of the data were performed using SPSS 18.0 software package (SPSS Inc, Chicago IL, USA).

\section{Results}

The mean age of the 1084 participants was $29.12 \pm 5.48$ years (min: 17, max: $46 \mathrm{y}$ ) and the average gestational age was $10.7 \pm 4.64$ weeks. HBsAg, anti-HBs, and anti-HCV detection rates were $4 \%(n=43), 7 \%(n=79)$, and $0.6 \%(n=7)$, respectively (Table 1). HBsAg was positive in $3 \%, 4 \%, 4 \%$, and $6 \%$ of the women who were below 20 years of age, between 21 and 30 years of age, between 31 and 40 years of age, and over 40 years of age, respectively. Anti-HCV and anti-HBs positivity rates in different age groups are shown in Table 2.

\section{Discussion}

HBV and HCV infections are the leading causes of cirrhosis, liver failure, and hepatocellular carcinoma (9). The reported prevalence of chronic HBV infection in the Turkish population ranges between $3 \%$ and $12.5 \%$ and transmission of the virus from HBsAg-positive mothers to newborns represents an important route for disease spread (10). Due to the high incidence of HBsAg positivity among pregnant women both in Turkey and in other countries, screening tests are very important for public health. The reported HBsAg positivity among Turkish pregnant women for the time period between 1987 and 2004 varies between 3.5\% and 9.3\% (11). The reported HBsAg prevalence rates from different countries exhibit significant variability, probably due to the influence of a number of factors including age, occupation, socio-economical status, IV drug use, blood transfusion, or sexual intercourse (12). For instance, a seropositivity rate of $10.8 \%$ for $\mathrm{HBsAg}$ has been detected among pregnant women in Yemen, however, screening of antenatal women is not routine in this country (13). A Nigerien study found a remarkably high incidence of $\mathrm{HBsAg}$ positivity, i.e. $16.6 \%$, among pregnant women, and the authors emphasized the importance of screening of pregnant women and vaccination of the newborns (14). In contrast with the respective prevalence rates of $4.6 \%$ (15), $2.9 \%(16)$, and $1.9 \%$ (17) in Nigeria, India and Bali, the reported

Table 1. HBsAg, anti-HBs, and anti-HCV seropositivity rates in pregnant women

\begin{tabular}{|l|l|l|l|}
\hline & HBsAg & Anti-HBs & Anti-HCV \\
\hline & $\mathbf{n}(\%)$ & $\mathbf{n}(\%)$ & $\mathbf{n}(\%)$ \\
\hline Positive & $43(4)$ & $79(7)$ & $7(0.6)$ \\
\hline Negative & $1041(96)$ & $1005(93)$ & $1077(99.4)$ \\
\hline Total & $1084(100)$ & $1084(100)$ & $1084(100)$ \\
\hline
\end{tabular}

Table 2. Distribution of HBsAg, anti-HBs and anti-HCV positivity in age groups

\begin{tabular}{|c|c|c|c|c|c|c|c|c|c|c|c|}
\hline Age groups & \multicolumn{3}{|c|}{$<20(n=64)$} & \multicolumn{2}{|c|}{$21-30(n=597)$} & \multicolumn{3}{|c|}{$31-40(n=406)$} & \multicolumn{3}{|c|}{$>40(n=17)$} \\
\hline $\begin{array}{l}\text { Seropositivity } \\
\text { rates } \%(n)\end{array}$ & & $\begin{array}{l}3 \\
(2)\end{array}$ & $\begin{array}{l}1.5 \\
(1)\end{array}$ & \begin{tabular}{|lr}
4 & 6 \\
$(22)$ & $(3$
\end{tabular} & $\begin{array}{l}0.1 \\
(2)\end{array}$ & \begin{tabular}{|l|}
4 \\
$(18)$
\end{tabular} & $\begin{array}{l}10 \\
(39)\end{array}$ & $\begin{array}{l}0.1 \\
(4)\end{array}$ & $\begin{array}{l}6 \\
(1)\end{array}$ & $\begin{array}{l}6 \\
(1)\end{array}$ & $\begin{array}{l}0 \\
0\end{array}$ \\
\hline
\end{tabular}


figures from Spain, Brazil, Peru, Ireland and North Italy are relatively lower, i.e. $0.4 \%(18), 0.5(19)$ and $0.7 \%(20), 0.6 \%(21), 0.7 \%(22)$, and $1 \%(23)$, respectively. The figures in our study (i.e. $4 \%$ ) are similar to those reported from Nigeria.

Previous studies from our country on the HBsAg and anti-HBs seropositivity rates display some degree of variability. Çopur Çiçek et al., reported anti-HBs prevalence of $25 \%$ in their study with one of the largest study samples that included a total of 56.275 pregnant women from Şanlıurfa (4). On the other hand, Kuru et al. detected a HBsAg prevalence of $4.2 \%$ in an Istanbul sample consisting of 5366 pregnant women (24). Similarly, in another study from Istanbul by Saveci, HBsAg and anti-HBs seroprevalence rates were $1.52 \%$ and $17.7 \%$, respectively (25). The prevalence of HBsAg and anti-HBs reported by Kölgelier et al. (26) from Adıyaman were $4.7 \%$ and $37.4 \%$, respectively. The corresponding figures from Kırıkkale by Sağsöz et al. (27) were $4.9 \%$ and $26.4 \%$, from Denizli by Kaleli et al. (28) were $7.6 \%$ and $22.75 \%$, and from Afyon by Yilmazer et al. (29) were $2.9 \%$ and $18.4 \%$. Also, Tosun et al. (30) reported a HBsAg positivity of $6.2 \%$ from Manisa province. Additionally, the figures reported by Coskun et al. (31) from Istanbul were $3.6 \%$ and $8.6 \%$, and from Kocaeli by Çakmak et al. (32) were $2.2 \%$ and $3.7 \%$, respectively. In our study, of the participating pregnant women, $4 \%$ were seropositive for $\mathrm{HBsAg}$ and $7.3 \%$ were seropositive for anti-HBs. Despite a similarity to previous reports in terms of HBsAg prevalence, except for some studies, the rate of anti-HBs positivity in our sample was lower as compared to the national average.

With regard to anti-HCV seropositivity rates, a significant variability in the reported figures can be noted. In studies involving pregnant women from India, Mali, Brazil, Spain, Switzerland, Puerto-Rico, and England the reported prevalence was less than $1 \%(16,18,20,33)$. On the other hand, the corresponding figures were $3.2 \%, 5.3 \%$, and $5.4 \%$ in Pakistan, Malawi, and Burkina Faso, respectively (34). Similar to previous studies from Turkey, the observed anti-HCV seroprevalence was $0.6 \%$ in our study. The reported rates by Çopur Çiçek et al. (4), Kölgelier et al. (26), Coşkun et al. (31), Çakmak et al. (32), Gönen (35), Atılgan et al. (36), and Kurdoğlu et al. (37) were 0.8\%, 0.2\%, 0.7\%, 0.3\%, 0.3\%, 0,44\%, and $0,54 \%$, respectively. Conversely, Karaca et al. and Gül et al. reported slightly higher figures, i.e. $1.3 \%$ and $2.4 \%$, respectively. On the other hand, seroprevalence of $0 \%$ was reported by Yılmazer et al. (29) and by Yücel et al. (4).

In conclusion, HBsAg and anti-HCV seroprevalence rates observed in this study were generally in line with previously reported figures from Turkey. On the other hand, the seroprevalence for anti-HBs was lower than in most other studies except for a few of them. This may be due to inadequate vaccination among women of reproductive age in Zonguldak area. Routine screening tests should be offered to all pregnant women with vaccination of those who are seronegative, and with appropriate administration of immunoglobulins and vaccines at the time of birth for those women who are HBsAg seropositive. Educational activities particularly focusing on those with a pre-marriage HBsAg positivity, provision of information on future partners regarding protection methods, and encouraging vaccination in those with anti-HBs negativity are important preventive targets.

\section{References}

1. Thomas D, Zoulim F. New challenges in viral hepatitis. Gut. 2012;61(1):1-5.

2. World Health Organisation 2012. Prevention\&Control of Viral Hepatitis Infection. Framework for Global Action.2012.

3. Ott JJ, Stevens GA, Groeger J, Wiersma ST. Global epidemiology of hepatitis B virusinfection: newestimates of age specific HBsAg seroprevalence and endemicity. Vaccine. 2012;30(12):2212-2219.

4. Cicek ÇA, Duygu $F$ ve Inakçı IH. Şanlıurfa Ilinde Kadın Hastalıkları ve Doğum Hastanesine Başvuran Kadınlarda Hepatit B ve Hepatit C Seroprevalansı: Üç- Yıllık Değerlendirme. Viral Hepatitis Journal. 2012;18(1):15-18.

5. Petrova M, Kamburov V. Breastfeeding and chronic HBV infection:Clinical and social implications. World J Gastroenterol. 2010;16:5042-5046.

6. Shepart CW, Finelli L, Alter J. Global Epidemiyology of Hepatitis C Virus Infection. Lancet Infect Dis. 2005;5;558-567.

7. Hupertz VF, Wyllie R. Perinatal hepatitis $C$ infection. Pediatr Infect Dis J. 2003;22:369-372.

8. Prasad MR, Honegger JR. Hepatitis $C$ virus in pregnancy. American journal of perinatology. 2013;30(2):149-159.

9. Pipili C, Cholongitas E. Management of patients with hepatitis $\mathrm{B}$ and $\mathrm{C}$ before and after liver and kidney transplantation. World J Hepatol. 2014;6(5):315-325.

10. Mıstık R. Türkiye'de viral hepatit epidemiyolojisi. Tabak F, Balık I, Tekeli E (eds). Viral Hepatit 2007. 1. Baskı. Istanbul: Viral Hepatitle Savaşım Derneği, 2007:10-50.

11. Tosun S. Türkiye'de viral hepatit B Epidemiyolojisi-Yayınların Metaanalizi. In: Tabak F, Tosun S (eds). Viral Hepatit 2013, 7. Basım. Istanbul: Istanbul Medikal Yayıncılık, Istanbul 2013:2581.

12. Hou J, Liu Z, Gu F. Epidemiology and Prevention of Hepatitis B Virus Infection. Int J Med Sci. 2005;2(1):50-57.

13. Murad EA, Babiker SM, Gasim GI, Rayis DA, Adam I. Epidemiology of hepatitis $B$ and hepatitis $C$ virus infections in pregnant women in Sana'a, Yemen. BMC Pregnancy Childbirth. 2013;13:127.

14. Mamadou S, Ide M, Maazou AR, Aoula B, Labo S, Bozari M. HIV infection and hepatitis $B$ seroprevalence among antenatal clinic attendees in Niger, West Africa. HIV AIDS (Auckl). 2012;4:1-4.

15. Obi SN, Onah HE, Ezugwu FO. Risk factors for hepaptitis B infection during pregnancy in a Nigerian obstetric population. Journal of Obstetrics and Gynecology. 2006;26(8):770-772.

16. Mehta KD, Antala S, Mistry M, Goswami Y. Seropositivity of hepatitis $B$, hepatitis $C$, syphilis, and HIV in antenatal women in India. J Infect Dev Ctries. 2013;7(11):832-837.

17. Surya GP, Kornia K, Suwardewa TG, Mulyanto, Tsuda F, Mishiro S. Serological markers of hepatitis B, C, E viruses and HIV type-1 infections in pregnant women in Bali, Indonesia. Journal of Medical Virology 2005;75:499-503.

18. Gutiérrez-Zufiaurre N, Sánchez-Hernández J, Muñoz S, Marín R, Delgado N, Sáenz MC, Muñoz-Bellido JL, García-Rodríguez JA. [Seroprevalence of antibodies against Treponema pallidum, Toxoplasma gondii, rubella virus, hepatitis $\mathrm{B}$ and $\mathrm{C}$ virus, and HIV in pregnant women]. Enferm Infecc Microbiol Clin. 2004;22(9):512-516.

19. Ferezin RI, Bertolini DA, Demarchi IG. [Prevalence of positive sorology for HIV, hepatitis B, toxoplasmosis and rubella in pregnant women from the northwestern region of the state of Paraná]. Rev Bras Ginecol Obstet. 2013;35(2):66-70.

20. Gonçalves MA, Matos Cde C, Spegiorin LC, Oliani DC, Oliani $\mathrm{AH}$, Mattos LC. Seropositivity rates for toxoplasmosis, rubella, 
syphilis, cytomegalovirus, hepatitis and HIV among pregnant women receiving care at a public health service,São Paulo state, Brazil. Braz J Infect Dis. 2010;14(6):601-605.

21. Vildozola $H$, Bazul V, Cambillo E. Prevalence of hepatitis B infection and risk factors in two groups of pregnant adolescents related to the number of sexual partners. Rev Gastroenterol Peru. 2006;26(3):242-258.

22. Mohebbi SR, Sanati A, Cheraghipour K, Rostami Nejad M, Shalmani HM, Zali MR. Hepatitis C and hepatitis B virus infection: epidemiology and risk factors in a large cohort of pregnant women in lorestan, west of Iran. Hepat Mon. 2011;11:736-739.

23. Baldo V, Fleroani A, Menegon T, Grella P, Paternoster DM, Trivello R. Hepatitis C virus, hepatitis Bvirus infection in pregnant Women in Nort - East Italy: a seroepidemiological study. Eur J Epidemiol. 2000;16(1):87-91.

24. Kuru U, Turan O, Kuru N, Saglam Z, Ceylan Y, Nurluoglu M, Agacfidan A. Prevalence of hepatitis $B$ virus infection in pregnant Turkish women and their families. Eur J Clin Microbiol Infect Dis. 1996;15:248-51.

25. S.B. Taksim Eğitim Ve Araştırma Hastanesi Kadın Hastalıkları Ve Doğum Kliniği, Gebelerde Hepatit B Seroprevalansı. Dr. Ebru Saveci. Aile hekimliği uzmanlık tezi. İstanbul 2006

26. Kolgelier S, Guler D, Demiraslan H. Adıyaman'da gebe kadınlarda HBsAg ve anti-HCV Sıklığı. Dicle Tıp Derg. 2009;36:191-194.

27. Sağsöz N, Apan T. Gebelerde tetanoz, hepatit B ve rubella seropozitiflik oranları. T Klin J Gynecol Obst. 2002;12:52-55.

28. Yılmazer M, Altındiş M, Cevrioğlu S, Fenkci V, Aktepe O, Sırthan E. Afyon bölgesinde yaşayan gebe kadınlarda toksoplazma, sitomegalovirus, rubella, hepatit $B$, hepatit $C$ seropozitiflik oranları. Kocatepe Tıp Dergisi. 2004;5:49-53.
29. Kaleli B, Kaleli I, Aktan E. Gebelerde ve bebeklerinin kordon kanlarında HBsAg. Perinatoloji Derg. 1997;5:42-43.

30. Tosun SY, Oruç S, Koyuncu FM, Özbakkaloğlu B, Karaer Ö. Gebelerde Hepatit B seroprevalansı. Jinekoloji Obstetrik Pediatri Dergisi. 1998;5-6:148-150.

31. Coşkun El, Dinçgez B, Koyucu RF, Ayanoğlu YT, Yumru AE. Gebelerde HBSAg, Anti-HBS ve Anti-HCV Sıklığı, Perinatoloji Dergisi. 2011;19(2):51-102.

32. Çakmak B, Karataş A. Kocaeli Bölgesinde Yaşayan Gebe Kadınlarda Hepatit B ve C Seropozitiflik Oranları. Selçuk Tıp Derg. 2012;28(2):80-82.

33. Bouare N, Vaira D, Gothot A, Delwaide J, Bontems S, Seidel L. Gerard P, Gerard C. Prevalence of HIV and HCV infections in two populations of Malian women and serological assays performances. World J Hepatol. 2012;4(12) 365-373.

34. Chasela CS, Wall P, Drobeniuc J, King CC, Teshale E, Hosseinipour MC, Ellington SR, Codd M, Jamieson DJ, Knight RJ, Fitzpatrick P, Kourtis AP, Hoffman IF, Kayira D, Mumba N, Kamwendo DD, Martinson F, Powderly W, van der Horst C, Kamili S; BAN team. Prevalence of hepatitis $C$ virus infection among human immunodeficiency virus-1-infected pregnant women in Malawi: the BAN study. J Clin Virol. 2012;54(4):318-320.

35. Gönen I. Kırsal Kesimde Gebelerde HBV ve HCV Sıklığı. Viral Hepatit Dergisi 2011;17(2):66-68

36. Atılgan R, Kavak SB, Çelik A. Gebelerde Hepatit B ve Hepatit C Seropozitiflik Oranları Turkiye Klinikleri J Gynecol Obst. 2009;19:34-37.

37. Kurdoğlu Z, Şirin Efe Ş. Van Ili'ndeki Kadınlarda Hepatit B, Hepatit C ve HIV Seroprevalansı. Van Tıp Derg. 2009;16:128130. 